\title{
4.2 'Das elektrische Rotkäppchen'
}

The text of Janosch's 'Das elektrische Rotkäppchen' ${ }^{1}$ opens with the insertion of the apparently meaningless adjective 'elektrisch' into the opening line from 'Rotkäppchen' (KHM 26):

Es war einmal eine süße elektrische Dirn $[\ldots]^{2}$

The narrative which follows continues to interpolate the word 'elektrisch' with verbatim phrases and slightly altered passages from Grimms' version of the tale. Although the repetitive use of this apparently simple, single technique creates the appearance that the text is a 'straightforward' piece of nonsense prose, the tales retold, modified and parodied in the collection in which 'Das elektrische Rotkäppchen' is to be found tend to be less widely known tales such as 'Herr Korbes' (KHM 41) and 'Doktor Allwissend' (KHM 181), with the choice of tales highlighting the diversity and complexity of the $K H M$. It is therefore unsurprising that a canonised tale such as 'Rotkäppchen' would be approached in this way, given that repetition of the historically incongruous word 'elektrisch' could be received by the reader as being directed against the widepread popular acceptance and canonised repetition of Grimms' version of 'Rotkäppchen'. Furthermore, the consistent interpolation of the word 'elektrisch' brings about semantic change in the preformed material appropriated from 'Rotkäppchen' (KHM 26) and creates comic discrepancy through incongruity, both of

\footnotetext{
Janosch (pseudonym for Horst Eckert): Janosch erzählt Grimms Märchen, pp. 102-107.

2 Janosch: 'Das elektrische Rotkäppchen', p. 102.
} 
which are 'foregrounded' by frequent repetition of the word. By setting up a relationship of apparent opposition between appropriated material and interpolation, this technique also foregrounds the presence of two strongly contrasting 'codes', and emphasises the ambivalent intertextuality involved in simultaneously recognising verbatim passages from 'Rotkäppchen' (KHM 26) and reading them juxtaposed with an incongruous, one word 'code'. This technique can hence be read as a signal for the presence of parody.

Upon closer examination of the use of the word 'elektrisch', it becomes apparent that the word is sometimes meaningful, but sometimes meaningless in the context of the narrative, producing a 'controlled discrepancy' between the parodic text and the source of preformed material through a combination of comic discrepancy and intertextual reference. Semantic change which increases the cohesion between the narrative and interpolated adjective occurs where the word is used to modernise the antiquated expression "wird sie sich daran laben", ${ }^{3}$ so that the expression becomes "[sie] soll sich damit ein bißchen elektrisieren". ${ }^{4}$ In a similar vein, "der Jäger", 5 who 'fixes' the Wolf, becomes "der Elektriker" ${ }^{6}$. However, seen in these terms, other uses of the word detract from the coherence of the narrative. The Wolf, "ein böses Tier", becomes "ein fürchterlicher und gemeiner Elektrisierer" ${ }^{8}$, and the injunction "sonst fällst du, und zerbrichst du das Glas,

3 'Rotkäppchen' (KHM 26), p. 157.

${ }^{4}$ Janosch: 'Das elektrische Rotkäppchen', p. 102.

5 'Rotkäppchen' (KHM 26), p. 159.

6 Janosch: 'Das elektrische Rotkäppchen', p. 107.

7 'Rotkäppchen' (KHM 26), p. 157.

${ }^{8}$ Janosch: 'Das elektrische Rotkäppchen', p. 102. 
dann hat die kranke Großmutter nichts" ${ }^{9}$ is transformed into "sonst verbiegst du dir einen Draht", ${ }^{10}$ which could be read as highlighting the incongruence between injunction and punishment in Grimms' version of the tale. Likewise, replacing "sieh einmal die schönen Blumen, die im Wald stehen" ${ }^{11}$ with "hast du die elektrischen Lampen im Wald nicht gesehen"12 whilst identifying all of the figures in the narrative as 'elektrisch' effectively destroys the dichotomy between Freiheit/ Wildheit/Natur and Schule/gerader Weg/Ordnung, originally created through the Mother's injunction and the Wolf's offer of temptation. The overall effect of the use of the word 'elektrisch' is thus to create internal consistency within the parodic text, but to detract from the coherence of Grimms' tale structure and moral messages, which can be read as calling into question the possibility that Grimms' text is a homogeneous narrative, and hence the possibility of unique or unequivocal interpretation of the tale.

In Grimms' version of 'Rotkäppchen', the parallel epilogue reinforces the moral message of the tale, in the form of a second, model encounter between Little Red Riding Hood, Grandmother and the Wolf. In 'Das elektrische Rotkäppchen', this epilogue appears as 'Das Rotkäppchenspiel', and begins with the following metafictional instruction to the reader:

Wer das Rotkäppchenspiel weiterspielen will, muß vor jedes Wort, wo es paßt, ein Eigenschaftswort setzen. $[\ldots]^{13}$

\footnotetext{
9 'Rotkäppchen' (KHM 26), p. 157.

10 Janosch: 'Das elektrische Rotkäppchen', p. 102.

11 'Rotkäppchen' (KHM 26), p. 157.

12 Janosch: 'Das elektrische Rotkäppchen', p. 104.

13 Janosch: 'Das elektrische Rotkäppchen', p. 107.
} 
This instruction combines with the narrator's earlier metafictional comment "eine elektrische Stunde weit hinter dem Märchenwald"14 ${ }^{14}$ to signal the type of text or preformed material appropriated, and the fact of its appropriation. The very attachment of the epilogue then directly throws the 'meaning' of the Grimmian material into question, by signalling the possibility of treating the parodic text not as a Märchen, or as employing parody, but rather as a game. By suggesting a process of creative reading, the text can be read as calling the epistemological situation of reading into question through metafictional comment. The addition of this epilogue then turns the text into a potentially serious game played with meaning, where the epilogue reproduces the game in a manner analogous to the reproduction of moral structure which takes place in 'Rotkäppchen' (KHM 26) through its parallel epilogue. The parodic text preserves significant portions of Grimmian content, transmitting the tale in a recognisable form whilst totally undermining its moral lesson, and hence 'refunctioning' the preformed material. The text could thus be read as setting out to encourage the kind of productive gameplaying which Jack Zipes suggests forms the emancipatory potential in the practical and educational use of fairy tales with children. ${ }^{15}$

Taking into account the text history of 'Rotkäppchen' ( $K H M$ 26) and the $K H M$, and the interpretative and didactic uses to which these texts have been put, many other readings of this parodic text are also possible, and are indeed encouraged by an understanding of parody as an inherently ambivalent inter-

14 Janosch: 'Das elektrische Rotkäppchen', p. 102.

15 Jack Zipes: "Bruno Bettelheim's Moralistic Magic Wand" in: Breaking the Magic Spell. 
pretative strategy. For example, the strong foregrounding of the apparently nonsensical adjective 'elektrisch' could also be read as comment on attempts at 'overlaying' interpretation on the tale, or as comment on the 'mechanised' reception and interpretation of Märchen. The consistent repetition of the word could be read as comment on the apparent stylistic consistency produced within the $K H M$ by Wilhelm Grimm's editorial process, or conversely, as restoring or highlighting the heterogeneous voicing and sourcing of the tale in the face of this editorial process. The use of the word 'elektrisch' could even be viewed as satiric comment on the commercialisation of Grimmian material in Märchenwälder or fairy tale theme parks. ${ }^{16}$ Hence, it can be seen that the application of an apparently simple, single parodic technique can be interpreted as generating complex semantic and rhetorical functions for the appropriated preformed material in its new context, through this understanding of parody and its interpretative possibilities.

${ }^{16}$ This possibility is offered as a definitive interpretation by Pischke: 'Das veränderte Märchen', p. 100. 